\title{
A new nematode, Pongobius hugoti gen. et sp. n. from the orangutan Pongo abelii (Primates: Hominidae)
}

\author{
V. BARUŠ ${ }^{1}$, I. FOITOVÁ ${ }^{2}$, B. KOUBKOVÁ ${ }^{2}$, I. HODOVÁ2 ${ }^{2}$ A. ŠIMKOVÁ2, W. NURCAHYO \\ ${ }^{1}$ Institute of Parasitology, Biology Centre of the Academy of Sciences of the Czech Republic, Branišovská 31, 37005 \\ České Budějovice, Czech Republic; ${ }^{2}$ Department of Botany and Zoology, Faculty of Science, Masaryk University, \\ Kotlářská 2, 61137 Brno, Czech Republic, E-mail: foitova@sci.muni.cz; ${ }^{3}$ Department of Parasitology, Kedokteran \\ Hewan Faculty, Gadjah Mada University, Yogyakarta, Indonesia
}

\begin{abstract}
Summary
Light and scanning electron microscopical examination and molecular analysis of pinworm samples collected from the Sumatran orangutan (Pongo abelii) from Sumatra (Indonesia) revealed the presence of a new taxon, Pongobius hugoti gen. et sp. n. (Oxyuridae: Enterobiinae). The monotypic genus Pongobius is characterised by the presence of a triangular mouth, three rounded teeth and three chisel-like inner teeth in the buccal cavity, an oesophagus with a long pharyngeal part, corpus posteriorly slightly enlarged and continuing as a pyriform bulb, isthmus absent. These features differentiate $P$. hugoti from all members of the subfamily Enterobiinae. The male has a long caudal appendix ( $>50 \%$ of total tail length). Molecular analysis of the new taxon is presented for more precise identification.
\end{abstract}

Key words: Pongobius hugoti gen. et sp. n.; Nematoda; Pongo abelii; orangutan; Sumatra; morphometric and molecular analyses

\section{Introduction}

The Sumatran orangutan, Pongo abelii Lesson, 1827, is distributed in Sumatra NW of Lake Toba (Wilson \& Reeder, 2005). From the critically-endangered great apes of the genus Pongo Lacépède, 1799, three pinworm species have been reported: Enterobius buckleyi Sandosham, 1950; E. foecundus (Linstow, 1879) and E. simiae (Mac Callum, 1921) according to Inglis (1961), Yamashita (1963) and Hugot (1999). Skrjabin et al. (1960) noted in this host the species E. anthropopitheci (Gedoelst, 1916); however, it is restricted to chimpanzees Pan troglodytes (Blumenbach, 1775) and P. paniscus Schwartz, 1929 as stated by Hugot (1993) and Hasegawa et al. (2005). Close examination of pinworms collected from orangutans from Sumatra led to the conclusion that they represent a new species and a new genus of the subfamily Enterobiinae Hugot, Gardner et Morand, 1996. Herein we describe and differentiate the new taxon, discovered following a long term project "Parasites and Natural Antiparasitics in Orangutan" conducted in Indonesia since 1999.

\section{Material and Methods}

The locality of investigation, the village Bukit Lawang (former Rehabilitation Center for Orangutans) is on the Southwest border of Gunung Leuser National Park (Northern Sumatra, Indonesia) $\left(03^{\circ} 32.983^{\prime} \mathrm{N}, 098^{\circ} 06.908^{\prime} \mathrm{E}\right)$ at an altitude of $1061 \mathrm{ft}$. Temperatures range between $21^{\circ} \mathrm{C}$ and $28^{\circ} \mathrm{C}$ with humidity between $80 \%$ and $100 \%$. Annual rainfall is 2,000-3,200 $\mathrm{mm}$. The majority of orangutans in this area live in a semi-wild population. From the fresh faeces of two adult female orang-utans, several worms were collected in 2002 and immediately fixed in $40 \%$ ethanol. For light microscopical examination, the nematodes were cleared gradually in glycerin and examined under a light microscope equipped with differential interference contrast (DIC), digital image analysis system (Micro Image 4.0 for Windows), and a drawing attachment was used for morphometric analysis. Parasites used for scanning electron microscopy (SEM) were washed several times in $0.6 \%$ saline, fixed with hot $4 \%$ formaldehyde solution and stored at room temperature. Prior to analysis, they were dehydrated through an ethanol series, dried in a CPD 030 critical point drying apparatus (Bal-tec) using liquid $\mathrm{CO}_{2}$, mounted on aluminium stubs with doublesided adhesive discs, coated with gold in a SCD 040 sputter coating unit (Balzers) and examined in a VEGA scan- 
ning electron microscope operating at $20 \mathrm{kV}$. Genomic DNA was extracted from ethanol-preserved tissues. DNA using the DNeasy Tissue Kit (QIAGEN). The partial 18S rDNA was amplified using the Mastercycler ep gradient $\mathrm{S}$ (Eppendorf) in a finale volume $30 \mu \mathrm{l}$ PCR reaction. Each amplification reaction contained $1 \mathrm{X}$ buffer, $1.5 \mathrm{mM} \mathrm{MgCl}$, $200 \mu \mathrm{M}$ dNTPs, 0.5 unit of Taq polymerase (Fermentas) and $0.5 \mu \mathrm{M}$ of each primer - Nem 18SF and Nem 18SR designed by Floyd et al. (2005). PCR was carried out with the following steps: an initial denaturation at $94{ }^{\circ} \mathrm{C}$ for 5 minutes, 35 cycles of $94{ }^{\circ} \mathrm{C}$ for 30 seconds, $54{ }^{\circ} \mathrm{C}$ for 30 seconds and $72{ }^{\circ} \mathrm{C}$ for 1 minute and final extension at 72 ${ }^{\circ} \mathrm{C}$ for 10 minutes. PCR products were separated on $1.5 \%$ agarose gel. PCR products were purified by Wizard ${ }^{\circledR} \mathrm{SV}$ Gel and PCR Clean-Up System (Promega) and sent for sequencing to Macrogen, Inc. (Korea) (for details see www.macrogen.com). Sequences were analysed using Sequencher software (Gene Codes Corporation).

\section{Results}

\section{Nematoda}

Oxyuridae Cobbold, 1864

Enterobiinae Hugot, Gardner et Morand, 1996

Pongobius n. gen.

Diagnosis: Oxyuridae, Enterobiinae. Body fusiform, medium sized. Mouth opening triangular, surrounded by three lips (wider than long). Lips distinctly separate from the head cuticular vesicle. Two nearby hemispherical papillae situated near base of dorsal lip. Each subventral lip bears a hemispherical papilla near ventral rim, and other papilla near lateral rim of lip, with conspicuous amphid opening. Mouth cavity contains three large teeth identical in form and shape. Dental apparatus complex is characterized by three inner chisel-like teeth. Oesophagus with long pharyngeal part, corpus posteriorly slightly enlarged and continuing in pyriform bulb with bulbar apparatus, opening
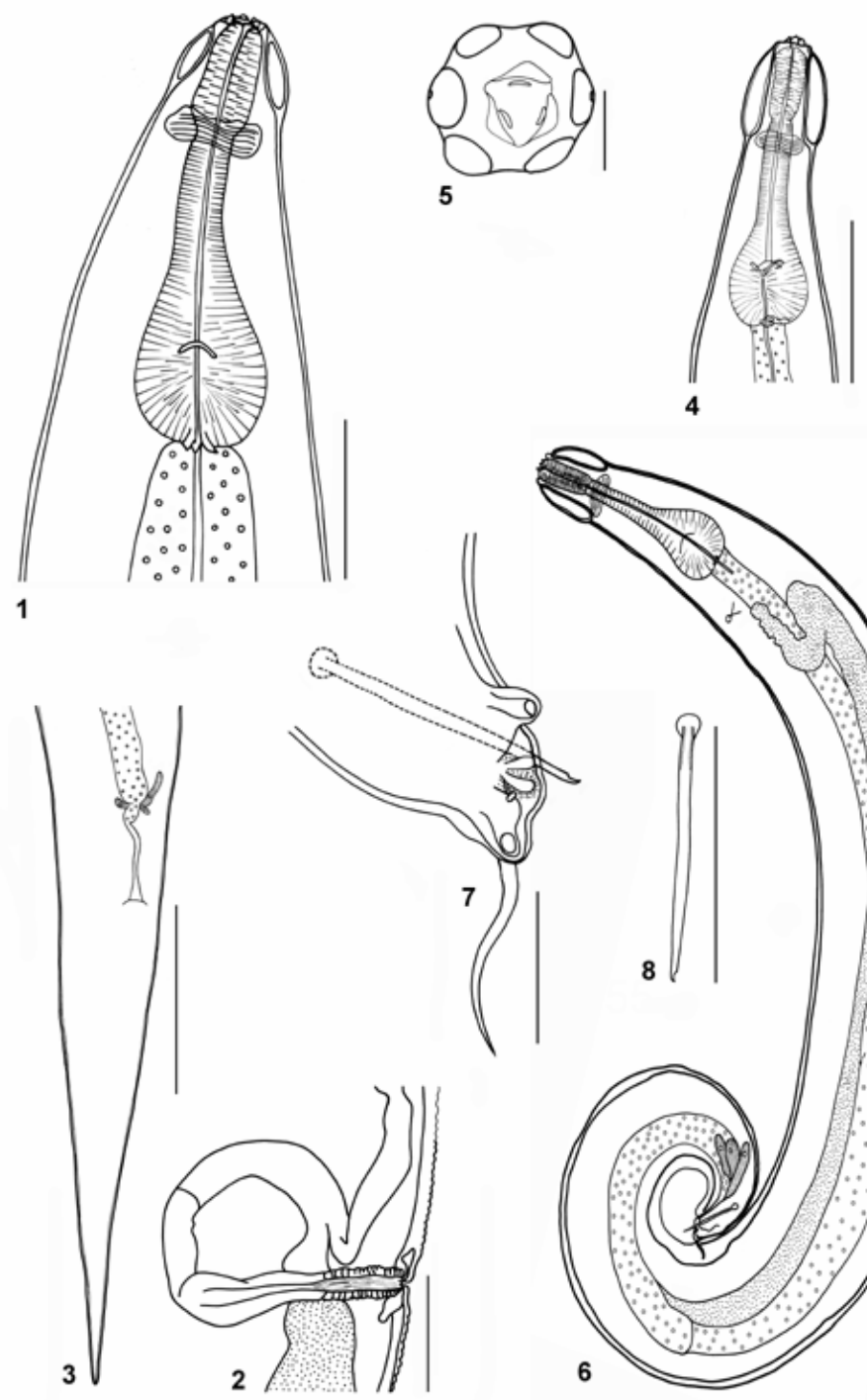

7

Plate I. Pongobius hugoti sp. n. from Pongo abelii

1. Cephalic end of female; 2. Vulva region - lateral view; 3. Tail end of female - ventrolateral view; 4. Cephalic end of male; 5 . Cephalic end of male - apical view, reconstructed from SEM micrographs; 6. Male - total lateral view; 7. Posterior extremity of male - lateral view; 8. spicule - lateral view

(Scale-bars: 1, 2, $4=200 \mu \mathrm{m} ; 3,6=500 \mu \mathrm{m} ; 5=20 \mu \mathrm{m} ; 7=50 \mu \mathrm{m} ; 8=100 \mu \mathrm{m}$ ) 

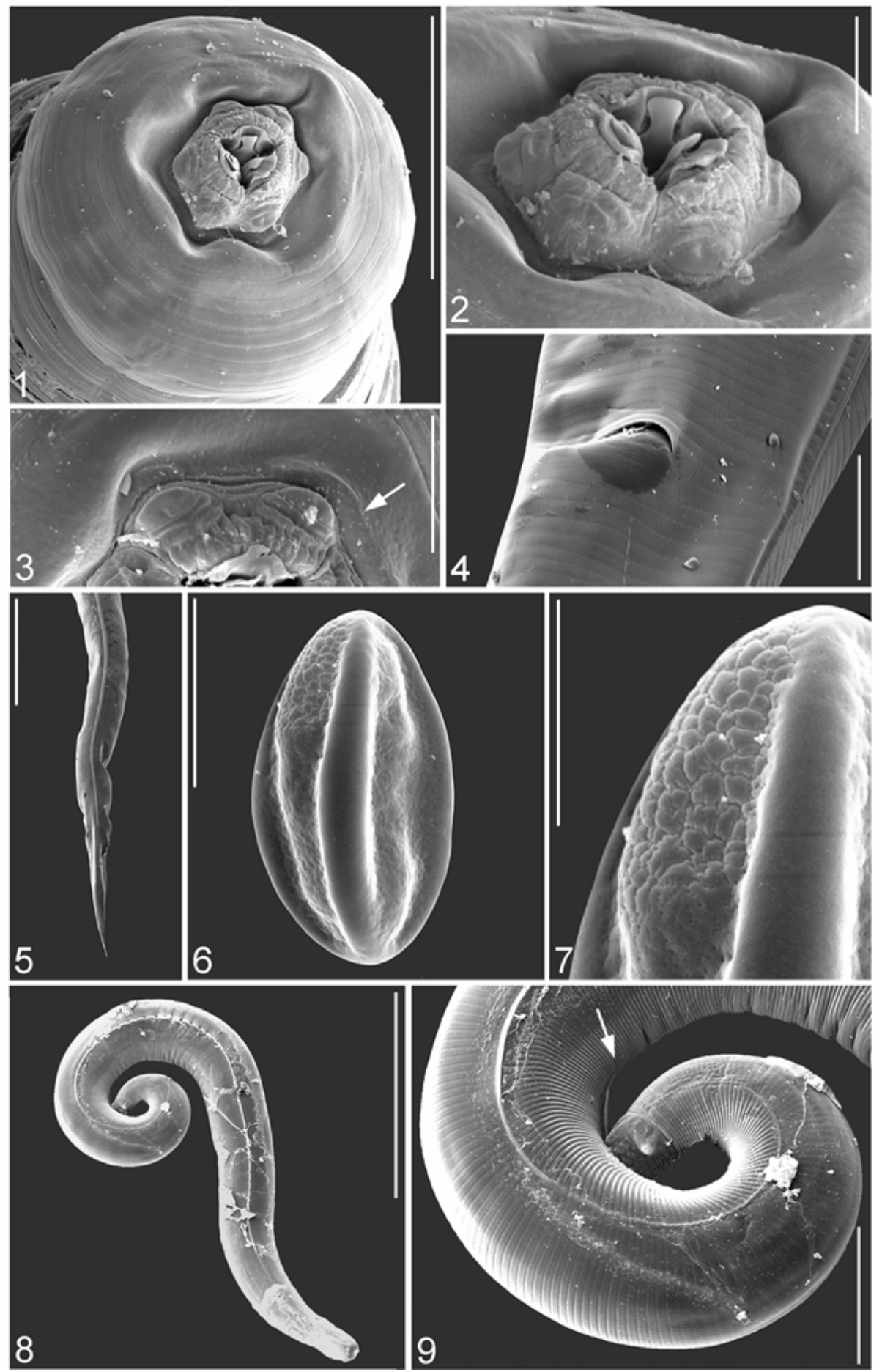

Plate II. Pongobius hugoti sp. n. from Pongo abelii, scanning electron micrographs

1. Cephalic end of female, apical view; 2. Cephalic end, lateroventral view; 3. Lateroventral lip, apical view (arrow: rugose circumoral zone); 4. Anus - detail, ventral view; 5. Tail of female, total view; 6. Egg, total view; 7. Egg - detail of subpolar plug; 8. Male, lateral view; 9. Detail of tail of male, lateral view (arrow: tail appendix)

(Scale-bars: $1,4,9=100 \mu \mathrm{m} ; 2,6=20 \mu \mathrm{m} ; 3=25 \mu \mathrm{m} ; 5=1000 \mu \mathrm{m} ; 7=10 \mu \mathrm{m} ; 8=500 \mu \mathrm{m}$ )

into intestine through small valves. Isthmus absent. Excretory pore postbulbar.

Male: Lateral alae with single crest; four pairs of caudal papillae, first and fourth pedunculate and support the bursa; and second and third pairs sessile, flanking slit-like opening of cloaca. Tubes of the phasmids begin at base of peduncles of fourth pair of caudal papillae. Each papilla of second pair is surrounded by ornamentation, which encircles third pair of genital papillae. Tail appendix present. Single spicule present, with wide manubrium.

Female: Lateral alae with double crest, suddenly widening from bulb base. Vulva pre-equatorial, followed by muscular vagina and uterine tube divided into two parts by cellular wall, forming diaphragm; no spermatheca observed. 
Eggs numerous, with three longitudinal thickenings; operculum subterminal, has a coarsely granulated texture, an irregular elliptical shape; and extends about one-quarter of total length of eggs. Tail long. (Plate I, II, III).

Pongobius hugoti sp. n.

Description: General. Medium sized, whitish nematodes. Cuticle with clear transverse striations; cephalic vesicle present and well developed with transverse markings. Lateral alae present. Mouth triangular, surrounded by three lips; cuticular circle ornamented by slightly rugose structure present in its base. Dorsal lip with two hemispherical papillae; two subventral lips each with two cephalic papillae, one of them with amphideal pore (Plate I/5, II/1, 2). Papillae separated from lip surface by fine incision. In buccal cavity, dental apparatus present, corresponding to respective lips, and consists of three wide and obtuse teeth apposed to lips and three inner chisel-like teeth protruding into buccal cavity (Plate II/2). Oesophagus with distinct muscular pharynx, corpus continuing to bulb, isthmus totally absent.

Female (10 specimens; measurements of holotype in parentheses; 9 paratypes, range and mean \pm S.D.). Lateral alae with double crest, suddenly widening from bulb base (Plate III). Length of body $6.21-9.33 ; 8.32 \pm 0.99(9.19)$ $\mathrm{mm}$; maximum width $466-750 ; 650 \pm 97.45$ (777); width at bulb $343-467 ; 411 \pm 63.77$ (515); at vulva $499-750$;
$645 \pm 87.13(739) \mu \mathrm{m}$; at anus $215-312 ; 272 \pm 42.39$ (354); cephalic vesicle length $94-142 ; 116 \pm 16.75$ (110); cephalic vesicle width $104-196 ; 169 \pm 27.33$ (179). Total oesophagus length $509-598 ; 556 \pm 30.13$ (594); pharynx length $127-158 ; 142 \pm 10.96$ (132); width $58-82 ; 70 \pm$ 8.04 (70); corpus length $139-200 ; 176 \pm 21.76$ (157); corpus width $62-107 ; 82 \pm 14.25$ (89); bulb length 194 $278 ; 241 \pm 39.61$ (308); bulb width $138-304 ; 233 \pm 62.84$ (314). Nerve ring $170-260 ; 206 \pm 36.84$ (237); excretory pore $772-1045 ; 941 \pm 91.42$ (941), vulva $1497-2554$; $2022 \pm 276.59$ (2085) from anterior extremity. Oviduct directed posteriorly, vagina very muscular, $184-492 ; 353$ \pm 96.32 (442) long, and $68-158 ; 121 \pm 24.75$ (132) wide. Vagina uterina divided into 2 portions by thick cellular wall (diaphragm) (Plate I/2). Distance between vulva and diaphragm longer than diaphragm and uterine opening. Amphidelphic. Tail long, conical, with pointed apex, 1251 - 1969; $1638 \pm 275.29$ (2087) (Plate I/3, II/4, 5).

Eggs $(\mathrm{n}=35)$ ellipsoidal, with flattened side, $41-50 ; 45 \pm$ 2.50 (44 - 46) long and $19-26 ; 23 \pm 2.40(22-23)$ wide, having three longitudinal thickenings (Plate II/6, 7; III/6, 7, 8). Ratios: Total body length/total oesophagus length 10.96 - 16.60; $14.96 \pm 1.63$ (15.48); total oesophagus length / pharynx length $3.44-4.60 ; 3.92 \pm 0.48(4.50)$; total body length / tail length $4.41-5.75 ; 5.07 \pm 0.45$ (4.41); total body length / vulva distance from anterior extremity $3.49-$

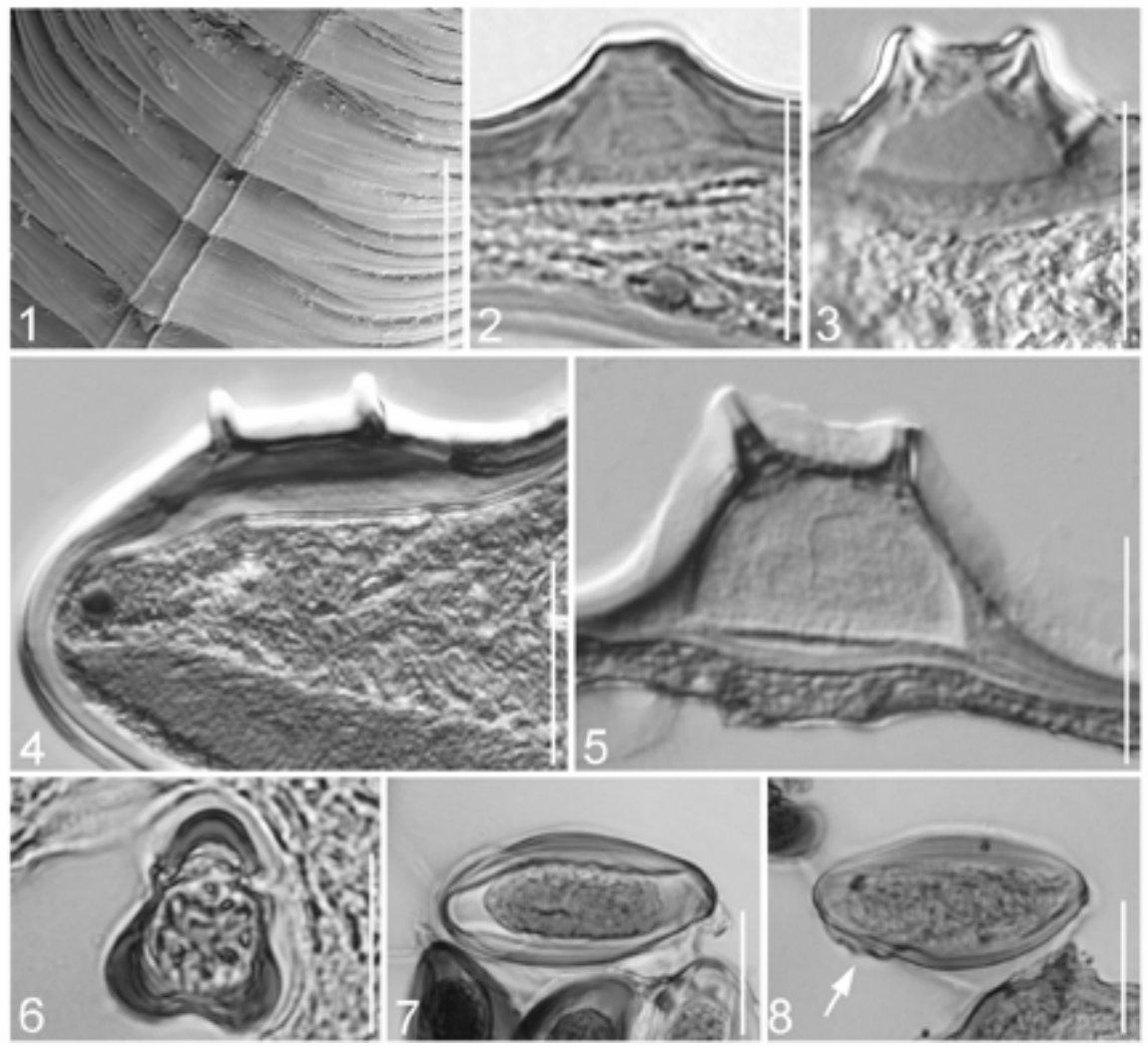

Plate III. Pongobius hugoti sp. n. from Pongo abelii, lateral alae and eggs

1. SEM - at level of oesophagus end, transition from narrower to wider part of lateral ala; 2 . Beginning of ala, transverse section; 3. Shaping of two crests of ala before their enlargement;

4. Lateral ala with double crest, middle part of body; 5 . Lateral ala, caudal part of body; 6. Transverse section of egg; 7 . Longitudinal section of egg;

8. Longitudinal section of egg, egg pole with granular structure

(Scale-bars: $1=100 \mu \mathrm{m} ; 3,4,5=25 \mu \mathrm{m} ; 2,6,7,8=20 \mu \mathrm{m}$ ) 
$5.15 ; 4.26 \pm 0.50(4.39)$.

Male (1 specimen; allotype)

Lateral alae with single crest beginning halfway between anterior extremity and nerve ring, and ending before caudal bursa (Plate II/8). Oesophagus ending in pyriform bulb; isthmus absent (Plate I/6). Length of body $2.69 \mathrm{~mm}$, maximum width 239 ; width at bulb 167 , width at excretory pore 226 ; at cloaca 49 . Cephalic vesicle length 126 , width 98. Total length of oesophagus 367, pharynx length 97, width 32 ; length of corpus 156 , width 31 ; bulb length 103 , width 92 . Nerve ring 116, excretory pore 722 from anterior extremity. Four pairs of caudal papillae present, first and fourth pairs pedunculate, second and third pairs sessile, flanking cloacal aperture (Plate I/7, II/9). Phasmidial tubes begin near origin of peduncles of fourth pair, rooted into long and fine conical tail, 104 long; tip of tail 80 long. One spicule present, well sclerotized, 104 long, with proximal manubrium 10 wide. Spicule width in middle part 7 , distal
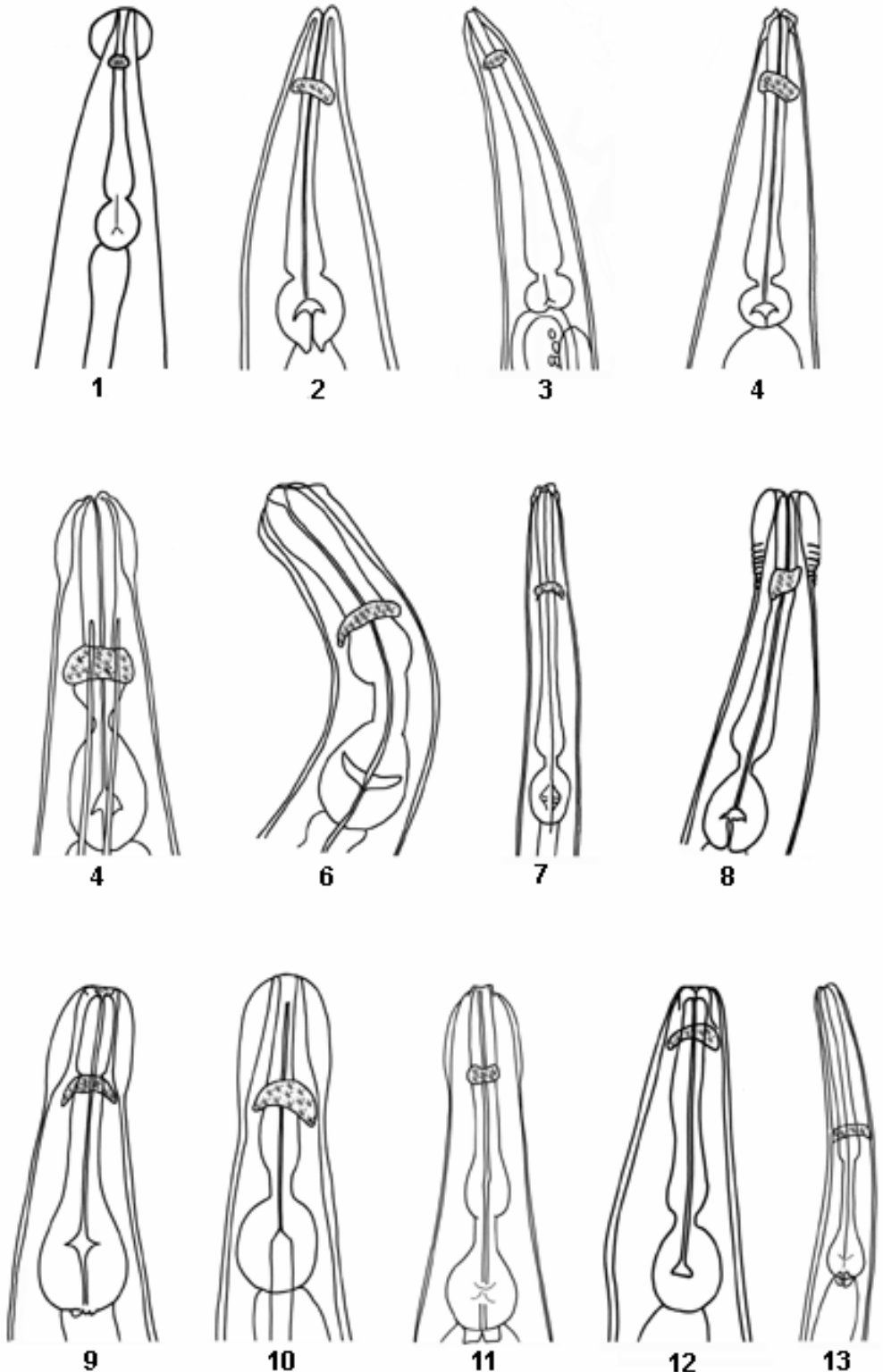

Plate IV. The females oesophagus form in genera and subgenera of the Enterobiinae. Not to same scale.

1. Enterobius (E. vermicularis L., 1758) - according to Skrjabin and Schulz 1928, in Skrjabin et al. (1960); 2. Colobenterobius (C. guerezae Hugot, 1987) - according to Hugot (1987); 3. Xeroxyuris (X. parallela Linstow, 1908) - according to Hugot (1995); 4. Trypanoxyuris (T. trypanoxyuris Vevers, 1923) - according to Hugot (1985); 5. Hapaloxyuris (H. goeldii Inglis et Gosgrove, 1965) - according to Hugot (1984b); 6. Oxyuronema (O. atelophora Kreis, 1932) - according to Hasegawa et al. (2004); 7. Buckleyenterobius (B. atelis Cameron, 1929) - according to

Hasegawa et al. (2004); 8. Rodentoxyuris (R. sciuri Cameron, 1932) - according to Hugot (1984a); 9. Pongobius gen. n. (P. hugoti sp. n. original); 10. Lemuricola (L. microcebi Hugot, Morand et Gardner, 1995) according to Hugot et al. (1995); 11. Protenterobius (P. nycticebi Baylis,

1928) - according to Inglis (1961); 12. Madoxyuris (M. daubentoniae Petter, Chabaud, Delavenay et Brygoo, 1972) - according to Petter et al. (1972); 13. Inglisoxyuris (I. inglisi Chabaud, Petter et Golvan, 1961) - according to Chabaud et al. (1961) 
part in form of small hook (in lateral view), with sharp point 4 long (Plate I/8). Ratios: Total body length/total oesophagus length 7.23 ; total oesophagus length/pharynx length 3.78 ; total body length/tail length 25.77 ; total oesophagus length/spicule length 3.51 .

Molecular analyses

Six individuals were used for molecular analysis. The fragment of $18 \mathrm{~S}$ rDNA, $910 \mathrm{bp}$ length, was amplified. The fragment of $782 \mathrm{bp}$ was readable after sequencing and used for our study. No intraspecific nucleotide variability was observed among the individuals studied. The significant alignment was produced in BLAST (http://www.ncbi.nlm. nih.gov) with 100 sequences of different nematode species including representatives of the Rhigonematida, Ascaridida, Rhabditida and Spirurida. The similarity between the sequence of $P$. hugoti sp. n. and other nematode sequences included in alignment ranged between $83 \%$ and $88 \%$ with the proportion of gaps ranging from $3 \%$ to $5 \%$. Distance trees using neighbour joining and fast minimum evolution methods produced by BLAST did not resolve the phylogenetic position of the sequenced pinworm. The sequence of P. hugoti sp. n. was deposited in GenBank database (http:// www.ncbi.nlm.nih.gov), accession number EU022678.

Type - host: Pongo abelii (Primates: Hominidae)

Site of infection: Intestine (discharged in faeces)

Type locality: North Sumatra, Bukit Lawang (0332.983' $\mathrm{N}, 098^{\circ} 06.908^{\prime} \mathrm{E}$ )

Number of specimens studied: measured 11 (one male, ten females); SEM 5 (one male, four females); molecular analyses 6 females.

Type material: Holotype, allotype and paratypes in the helminthological collection of the Institute of Parasitology, ASCR, in České Budějovice (Cat. No. N-882) and 5 specimens in the Department of Parasitology, Gadjah Mada University, Yogyakarta, Indonesia.

Etymology: The generic name Pongobius relates to generic name of the host (the great ape Pongo), with the suffix bius which is the same as the name of the type genus (Enterobius). The species is named for the distinguished French helminthologist Dr. J. P. Hugot, who contributed greatly to the knowledge of systematics and taxonomy in oxyurids parasitising primates and other mammals.

\section{Discussion}

Pinworms represent the parasite group occurring in most families and genera of the order Primates. The subfamily Enterobiinae includes 47 species of pinworms parasitising primates, and three species parasitising rodents (see Quentin \& Tenora, 1975; Hugot, 1984a, b, 1995, 1999; Hugot et al., 1996; Sorci et al., 1997; Hugot \& Baylac 2007). Recently Hasegawa et al. (2002, 2003) described two new species of pinworms from monkeys.

A cladistic analysis made by Hugot (1999) confirmed the monophyly of the subfamily, and also the monophyly of three main genera (or groups of genera and related subgenera). We accept, according to Hugot et al. (1996), Hugot (1999), Hasegawa et al. (2004), and Hugot and Baylac
(2007), the following generic or subgeneric units: 1. Enterobius Leach, 1853; 2. Colobenterobius Quentin, Betterton et Krishasamy, 1979; 3. Xeroxyuris Hugot, 1995; 4. Madoxyuris Chabaud, Brygoo et Petter, 1959; 5. Rodentoxyuris Quentin et Tenora, 1974; 6. Lemuricola Chabaud et Petter, 1959 (syn. Biguetius Chabaud, Brygoo et Petter, 1965); 7. Protenterobius Inglis, 1961; 8. Trypanoxyuris Vevers, 1923 (syn. Lobatorobius Skrjabin et Schikhobalova, 1959); 9. Hapaloxyuris Inglis et Cosgrove, 1965; 10. Oxyuronema Kreis, 1932 (syn. Paraoxyuronema Artigas, 1936 pro parte, sensu Hugot et al. 1996); 11. Buckleyenterobius Sandosham, 1950 (syn. Odontorobius Skrjabin et Schikhobalova, 1951; Paraoxyuronema Artigas, 1936 pro parte, sensu Hugot et al. 1996). The monotypic genus Inglisoxyuris Chabaud, Petter et Golvan, 1961 was previously classified as a subgenus of Lemuricola. According to Hugot et al. (1996), the species I. inglisi does not share the characters of the subfamily Enterobiinae, and until its precise classification it should be referred to this species as an Oxyuridae sensu lato.

The general morphology of Pongobius hugoti sp. n. from Pongo abelii clearly indicates that the species belongs to the Enterobiinae. It differs from all species of the subfamily in having a long pharynx and an oesophagus without an isthmus (Plate IV). We believe, like Hasegawa et al. (2004), that the characteristic form of the oesophagus in both sexes is a significant systematic trait. The male of $P$. hugoti sp. n. has a long caudal appendix, similar to that in Lemuricola; species of other genera - Protenterobius, Trypanoxyuris, Hapaloxyuris, Oxyuronema, Buckleyenterobius, Rodentoxyuris and Inglisoxyuris - have a markedly shorter caudal appendix ( $<50 \%$ of total tail length). Species of Enterobius and Colobenterobius have no tail or caudal appendix, Madoxyuris and Xeroxyuris also lack a caudal appendix (see Quentin \& Tenora, 1975; Quentin et al., 1979; Hugot, 1984a, b, 1985, 1987, 1995; Hugot \& Tourte-Schaeffer, 1985). P. hugoti sp. n. differs from species of Lemuricola in a relatively shorter posterior part with phasmids slightly posterior to the juxta-cloacal papillae, similar to Protenterobius (see Hugot \& Baylac, 2007). The cephalic and buccal characters of the Enterobiinae are of species and generic significance (Tenora et al., 1981; Hugot et al., 1996). In the presence of three obtuse buccal teeth, and three well-developed inner chisellike teeth $P$. hugoti sp. n. differs distinctly from all genera (and subgenera) of the Enterobiinae (survey in Hugot et al., 1996; Hasegawa et al., 2004). The general morphology of our parasites indicates they are closely related to species of Lemuricola and Protenterobius, but its specific morphology (mainly the form of the oesophagus, head and teeth structures) differentiates it from all primate pinworms (Enterobiinae). Therefore, a new genus and species are proposed for the nematode. The molecular analysis of the new taxon was investigated for more precise identification. As mentioned above, the following nominal taxa were found in the orangutan: E. buckleyi, E. foecundus, and E. simiae, all having a short but obvious oesophageal isthmus. The first two species differ from the new species by the 
absence of the tail appendix. E. simiae was correctly considered as a species inquirenda by Sandosham (1950). Inglis (1961) preferred to consider this species, and probably also E. foecundus, as nomina dubia. According to the original description by Sandosham (1950), E. buckleyi, parasitising the Bornean orangutan Pongo pygmaeus (Linnaeus, 1760), differs from Pongobius hugoti sp. n. by the longer oesophagus (male 570, female 900-990), spicule length (122) with rounded distal tip, larger eggs $(56 \times 26)$, and location of vulva nearer the middle of the body (ratio body length/vulva distance of anterior extremity $=1: 1.70$ $-1.78)$.

Due to the relatively high differences between the partial $18 \mathrm{~S}$ rDNA sequences of $P$. hugoti $\mathrm{sp}$. n. compared to other nematode species available in GenBank, we propose that this marker could be applied for molecular identification of $P$. hugoti sp. n. However, analyses of closely related species from the genera Lemuricola or Protenterobius should be performed to estimate the level of interspecific variability. Moreover, we suggest the need for broader phylogenetic analyses of a range of nematode species to solve the phylogenetic position of Pongobius hugoti sp. n. For further molecular analyses, we also propose to analyse the mitochondrial cytochrome $c$ oxidase subunit 1 (CO1) gene and nuclear internal transcribed spacer 2 rDNA (ITS2) region of Pongobius hugoti sp. $\mathrm{n}$. The analyses of those genes were recently applied for the molecular identification of Enterobius vermicularis and the phylogenetic analyses of pinworms in humans and chimpanzees (Nakano et al., 2006).

\section{Acknowledgement}

The authors would like to thank the Indonesian Institute of Sciences (LIPI) and PHKA for a research permit to work in Gunung Leuser National Park. The study was financially supported by the Foundation "UMI - Saving of Pongidae" Parasites and Natural Antiparasitics in Orangutan, and by the Research project of Masaryk University 0021622416. The author would also like to thank anonymous reviewers for their helpful comments and Karen Jeffers for editing the English manuscript.

\section{References}

Chabaud, A. G., Petter, A. J., Golvan, Y. (1961): Les nematodes parasites de lémuriens Malgaches III. Collection récoltée par M. et Mme Francis Petter. Ann. Parasit. Hum. Comp., 36: 113 - 126

Floyd, R. M., Rogers, A. D., LAmbshead, J. D., SMIth, C. (2005): Nematode-specific PCR primers for the $18 \mathrm{~S}$ small subunit rRNA gene. Mol. Ecol. Notes, 5: 611 - 612 Hasegawa, H., Matsuo, K., Onuma, M. (2003): Enterobius (Colobenterobius) serratus sp. nov. (Nematoda: Oxyuridae) from the Proboscis Monkey, Nasalis larvatus (Wurmb, 1787) (Primates: Cercopithecidae: Colobinae), in Sarawak, Borneo, Malaysia. Comp. Parasitol., 70: 128 131
Hasegawa, H., Murata, K., Asakawa, M. (2002): Enterobius (Colobenterobius) pygatrichus sp.n. (Nematoda: Oxyuridae) Collected from a Golden Monkey Pygathrix roxellana (Milne-Edwards, 1870) (Primates: Cercopithecidae: Colobinae). Comp. Parasitol., 69: $62-65$

Hasegawa, H., IKedA, Y., DiAZ-AQuino, D.J.J., FuKui, D. (2004): Redescription of two pinworms from the blackhanded spider monkey, Ateles geoffroyi, with reestablishment of Oxyuronema and Buckleyenterobius (Nematoda: Oxyuroidea). Comp. Parasitol., 71: 166 - 174

Hasegawa H., IKeda Y., Fujisaki A., Moscovice, L.R., Petrzelkova, K. J., Kaur, T., Huffman, M.A. (2005): Morphology of chimpanzee pinworms, Enterobius (Enterobius) anthropopitheci (Gedoelst, 1916) (Nematoda: Oxyuridae), collected from Chimpanzees, Pan troglodytes, on Rubondo Island, Tanzania. J. Parasitol., 91: 1314 1317

Hugot, J.P. (1984a): Sur le genre Trypanoxyuris (Oxyuridae, Nematoda): I. Parasites de Sciuridés: sousgenre Rodentoxyuris. B. Mus. Natl. Hist. Nat., Série A, Zoologie, 6: $711-720$

Hugot, J. P. (1984b): Sur le genre Trypanoxyuris (Oxyuridae, Nematoda) II. Sous-genre Hapaloxyuris parasites de Primates Callitrichidae. B. Mus. Natl. Hist. Nat., Série A, Zoologie, 6: 1007 - 1019

Hugot, J. P. (1985): Sur le genre Trypanoxyuris (Oxyuridae, Nematoda) III. Sous-genre Trypanoxyuris parasite de primates Cebidae et Atelidae. B. Mus. Natl. Hist. Nat., Série A, Zoologie, 7: $131-155$

HugOT, J. P. (1987): Sur le genre Enterobius (Oxyuridae, Nematoda): s.g. Colobenterobius I. Parasites de Primates Colobinae en region éthiopienne. B. Mus. Natl. Hist. Nat., Série A, Zoologie, 9: 341 - 352

Hugot, J. P. (1993): Redescription of Enterobius anthropopitheci (Gedoelst, 1916) (Nematoda, Oxyuroidea), a parasite of chimpanzees. Syst. Parasit., 26: 201 - 207

HugOT, J. P. (1995): Redescription of Xeroxyuris parallela (Linstow, 1908) n. gen., n. cb., parasite of Xerus inauris. Parasite, 2: $1-7$

Hugot, J. P. (1999): Primates and their pinworm parasites: Cameron hypothesis revisited. Syst. Biol., 48: 523 - 546

HugOt, J. P., BAYlaC, M. (2007): Shape patterns of genital papillae in pinworms (Enterobiinae, Oxyurida, Nematoda) parasite of primates: A landmark analysis. Inf. Gen. Evol., 7: $168-179$

Hugot, J. P., Tourte-Schaffer, C. (1985): Etude morphologique des deux oxyures parasites de 1'Homme: Enterobius vermicularis et E. gregorii. Ann. Parasit. Hum. Comp., 60: $57-64$

Hugot, J. P., Gardner, S. L., Morand, S. (1996): The Enterobiinae subfam. nov. (Nematoda, Oxyurida) pinworm parasites of primates and rodents. Int. J. Parasitol., 26: 147 $-159$

Hugot, J. P., Morand, S., Gardner, S. L. (1995): Morphology and morphometric of three oxyurids parasitic in primates with a description of Lemuricola microcebi n.sp. Int. J. Parasitol., 25: 1065 - 1075

INGLIS, W. G. (1961): The oxyurids parasites (Nematoda) 
of primates. P. Zool. Soc. Lond., 136: $103-122$

NaKano, T., OKamoto, M., IKeda, Y., Hasegawa, H. (2006): Mitochondrial cytochrome $c$ oxidase subunit 1 gene and nuclear rDNA regions of Enterobius vermicularis parasitic in captive chimpanzees with special reference to its relationship with pinworms in humans. Paras. Res., 100: $51-57$

Petter, A. J., Chabaud, A. G., Delavenay, R., Brygoo, E. R. (1972): Une nouvelle espéce de Nématode du genre Lemuricola, parasite de Daubentonia madagascariensis Gmelin, et considérations sur le genre Lemuricola. Ann. Parasit. Hum. Comp., 47: $391-398$

Quentin, J. C., TenORA, F. (1975): Morfologie et position systématique de Lemuricola (Rodentoxyuris) sciuri (Cameron, 1933) nov. comb., nov. subg., et Syphacia (Syphatineria) funambuli Johnson, 1967. Oxyures (Nematoda) parasites de Rongeurs Sciurides. B. Mus. Natl. Hist. Nat., Serie A, Zoologie, 178: 1525 - 1535

Quentin, J. C., Betterton, C., Krishnasamy, M. (1979): Oxyures nouveaux ou peu connus, parasites de Primates, de Rongeurs et de Dermoptères en Malaisie. Création du sous-genre Colobenterobius n. subg. B. Mus. Natl. Hist.
Nat., Serie A, Zoologie, 1: 1031 - 1050

SANDOSHAM, A. A. (1950): On Enterobius vermicularis (Linnaeus, 1758) and some related species from primates and rodents. J. Helmintol., 24: $171-204$

SkRJABIN, K. I., SCHIKHOBAlOVA, N. P., LAgOdovsKaya, E. A. (1960): Oxyurids of animals and man. Principles of Nematodology, Vol. 8, Publ. House AN SSSR, Moscow, 557 pp. (In Russian)

Sorci, G., Morand, S., Hugot, J. P. (1997): Host parasites coevolution: comparative evidence for covariation of life history traits in primates and oxyurid parasites. $P$. Zool. Soc. Lond., 264: 285 - 289

TENORA, F., BARUŠ, V., Wiger, R., RYŠAVÝ, B. (1981): Scanning electron microscopic studies on nematode species of the genera Passalurus, Enterobius and Lemuricola (Oxyurida). Acta U. Agr. Fac. Agron., 29: 327 - 339

WILSON, D. E., REEDER, D. A. (2005): Mammals species of the world. A taxonomic and geographic reference. Vol.1. The Johns Hopkins University Press, Baltimore, 743 pp. YAMASHITA, J. (1963): Ecological relationships between parasites and Primates. I. Helmith parasites and primates. Primates, 4: 1 - 35 